\title{
NALAR INTEGRASI FIKIH DAN PSIKOLOGI KELUARGA DALAM PANDANGAN HAKIM AGAMA JAWA TIMUR TENTANG HAK ASUH ANAK PASANGAN MURTAD
}

\author{
M. Ghufron \\ UIN Sunan Ampel \\ Surabaya \\ ghufron242@gmail.com
}

Moh. Ali

UIN Sunan Ampel

Surabaya

alialwahid07@gmail.com

\begin{abstract}
One of the causes of divorce which was decided by a Religious Court judge was because of the apostasy of one of the spouses. Divorce due to apostasy leaves problems in parenting. To whom the child custody will be given must be considered by the judge. This research is empirical research (field study) with fiqh and family psychology approach to get an understanding of the basic considerations of judges in establishing child custody in the case of an apostate partner. Through interviews and documentation, the study found, that the consideration of judges based on three things: first, normative basis, which is based on the consideration of Constitution No. 1 of 1974, Compilation of Islamic Law, Constitution No. 7 of 1989 Jo. Constitution Number 30 of 2006 concerning Childcare, and Number 23 of 2002, Supreme Court jurisprudence Number 210 / K/ $A G$ / 1990. Second, fiqh basis, which refers to the requirements of the Hadhanah which are in line with fiqh and the provisions of the Hadhanah based on Syafii's Madzab. Third, the psychological basis, which considers all psychological problems related to children. By using this integrative analysis the judge considers that the requirements for Muslims to care for children are in line with psychological values, that the family must provide Islamic education to shape the child's mental spirit.
\end{abstract}

Keywords: Judge's Opinions, Child Custody, Apostate Couple, Fiqh, Family Psychology

Abstrak: Salah satu penyebab perceraian yang diputus hakim Pengadilan Agama adalah karena 
murtadnya salah satu pasangan. Perceraian karena sebab murtad menyisakan problem pada pengasuhan anak. Kepada siapa hak asuh anak akan diberikan harus dipertimbangkan oleh hakim. Penelitian ini termasuk penelitian empiris (studi lapangan) dengan pendekatan fiqh dan psikologi keluarga untuk mendapatkan pemahaman tentang dasar pertimbangan hakim dalam menetapkan hak asuh anak pada kasus pasangan murtad. Melalui metode wawancara dan dokumentasi, penelitian ini menemukan, bahwa pertimbangan hakim didasarkan pada tiga hal: pertama, dasar normatif, yaitu pertimbangan berdasar Undang-Undang Nomor 1 Tahun 1974 Tentang Perkawinan, Kompilasi Hukum Islam, Undang-Undang Nomor 7 tahun 1989 Jo. Undang-Undang Nomor 30 tahun 2006 Tentang Pengasuhan Anak, dan Nomor 23 tahun 2002, yurisprudensi Mahkamah Agung Nomor 210 / K / AG / 1990. Kedua, dasar fiqh, yaitu mengacu pada persyaratan haḍānah yang sejalan dengan fiqh dan ketentuan hadānah berdasarkan Madzab Syafiii. Ketiga, dasar psikologis, yaitu mempertimbangkan semua masalah terkait psikologis anak. Dengan menggunakan analisis integratif tersebut hakim mempertimbangkan, bahwa persyaratan harus muslim untuk mengasuh anak, sudah sejalan dengan nilai-nilai psikologis, bahwa keluarga harus memberikan pendidikan Islam untuk membentuk mental spiritual anak.

Kata Kunci: Pandangan Hakim, Hak Asuh Anak, Pasangan Murtad, Fiqh, Psikologi Keluarga.

\section{Pendahuluan}

Perkawinan sesuai dengan syariat Islam, merupakan salah satu cara untuk menjaga kehormatan diri sendiri dan pasangan, agar tidak terjerumus pada hal-hal yang diharamkan. Perkawinan juga berfungsi menjaga komunitas manusia dari kepunahan, yakni dengan melahirkan dan mempunyai keturunan, menjaga kesinambungan garis keturunan, menciptakan keluarga yang harmonis, menciptakan sikap 
bahu-membahu antar suami isteri untuk mengemban amanah kehidupan. Perkawinan merupakan akad kasih sayang dan tolong-menolong di antara golongan, dan penguat hubungan antar keluarga, selain juga untuk menjaga keutuhan dan kekokohan agama.1 Tujuan perkawinan yang terakhir, sebenarnya tidak kalah penting dari tujuan lainnya. Mengingat agama merupakan tuntunan utama dalam mengarungi kehidupan dalam bahtera rumah tangga yang telah dibangun melalui akad perkawinan yang sah, karena setelah ada perkawinan akan ada pula anak, buah perkawinan yang merupakan bukti kebesaran Allah dalam memberikan karunia dan kebahagiaan hidup berkeluarga.

Tetapi, seiring dengan berjalannya waktu dan perkembangan jaman, beberapa dari pasangan suami istri tidak bisa terhindar dari problematika kehidupan rumah tangga. Ada yang dapat melaluinya sebagai bentuk ujian atas kebahagiaan yang didapat, ada pula yang harus bercerai/ berpisah karena tidak dapat melalui problem yang ada, bahkan sampai pada titik akhir, yakni harus melaui serangkaian sidang perceraian. Dalam KHI pasal 116 dijelaskan bahwa perceraian dapat terjadi karena alasan atau alasan-alasan berikut ini:2

1. Salah satu pihak berbuat zina atau menjadi pemabuk, pemadat, penjudi dan lain sebagainya yang sukar disembuhkan;

2. Salah satu pihak meninggalkan pihak lain selama dua (2) tahun berturut-turut tanpa izin pihak lain dan tanpa alasan yang sah atau karena hal diluar kemampuannya;

3. Salah satu pihak mendapat hukuman penjara lima (5) tahun atau hukuman yang lebih berat setelah perkawinan berlangsung;

4. Salah satu pihak melakukan kekejaman atau penganiayaan berat yang membahayakan pihak lain;

1 Wahbah Al-Zuhaili, Fiqih Islam Wa Adilatuhu, Jilid 9, terj. Abdul Hayyie alKattani dkk., (Jakarta: Gema Insani, 2011), 40-41.

2Himpunan Undang-Undang Republik Indonesia Nomor 1 Tahun 1974 tentang Perkawinan \& Kompilasi Hukum Islam, (Jakarta: Grahamedia Press, 2014), 365. 
5. Salah satu pihak mendapat cacat badan atau penyakit dengan akibat tidak dapat menjalankan kewajibannya sebagai suami atau isteri;

6. Antara suami isteri terus menerus terjadi perselisihan dan pertengkaran dan tidak ada harapan akan hidup rukun lagidalam rumah tangga;

7. Suami melanggar taklik talak;

8. Peralihan agama atau murtad yang menyebabkan terjadinya ketidakrukunan dalam rumah tangga.

Berkenaan dengan hak asuh anak pasangan murtad, yakni pengasuhan anak oleh orang tua yang bercerai karena keluar dari Islam, dalam ketentuan pasal 1 ayat (11) Undang-Undang Nomor 23 Tahun 2002 Tentang Perlindungan Anak, dijelaskan tentang pengertian kekuasaan orang tua yang dalam mengasuh dan menumbuhkembangkan anak harus sesuai dengan agama yang dianutnya. Sementara Pasal 42 ayat (2) Undang-Undang Nomor 23 Tahun 2002 Tentang Perlindungan Anak dinyatakan bahwa agama anak, sebelum ia dapat menentukan pilihannya, mengikut agama orang tuanya. Dalam pasal ini tidak ada penjelasan tentang bagaimana jika agama kedua orang tuanya berbeda. Adapun Pasal 31 ayat (4), mengatur kuasa asuh yang dilaksanakan oleh selain orang tua kandung jika orang tua kandung tidak ada, tidak diketahui keberadaannya, karena suatu sebab tidak dapat melaksanakan kewajiban dan tanggung jawabnya sehingga dialihkan ke keluarga atau orang perseorangan atau lembaga pemerintah/masyarakat yang disyaratkan harus seagama dengan si anak.3

Perkembangan jaman, pola perilaku, serta tuntutan kehidupan, seringkali membuat hubungan suami-istri dalam rumah tangga bersitegang. Ketidakmampuan pasangan mengatasi konflik dalam rumah tangga seringkali menyebabkan mereka memilih bercerai, meskipun di antara mereka telah lahir anak. Dalam kasus perceraian dengan sebab murtadnya salah satu pasangan, peran hakim sangat penting

3Undang-Undang Nomor 23 Tahun 2002 Tentang Perlindungan Anak. 
dalam menentukan masa depan anak dengan cara memberikan hak asuh anak kepada orang yang tepat.

Dalam konsep Islam tentang pemeliharaan anak, mayoritas ulama sepakat, bahwa kalangan perempuan lebih berhak menjalankannya ketimbang kalangan laki-laki, karena mereka punya sifat belas kasih, telaten dalam merawat, sabar dan lebih intens dalam menjaga anak. Hanya saja, ulama berbeda-beda dalam menentukan urutan-urutan siapa yang lebih utama.

Di sisi lain, penulis menemukan beberapa putusan Hakim Pengadilan Agama tentang hak asuh anak yang ibunya murtad dan tetap menjatuhkan hak asuh anak kepada sang ibu, padahal jelas sang ibu keluar dari agama Islam. Penting kiranya dilakukan kajian lebih jauh tentang alasan-alasan hakim tetap memberikan hak asuh anak kepada orang tua yang murtad ini. Kajian ini adalah hasil penelitian empiris religius-psikologis dengan pendekatan fikih dan psikologi keluarga yang berupaya mendapatkan pemahaman tentang dasar pertimbangan hakim dalam perkara hak asuh anak pasangan murtad.

Beberapa kajian tentang hak asuh anak yang kedua orang tua atau salah satunya murtad telah dilakukan, misalnya karya M. Alfian Azizi yang berjudul Analisis Hukum Islam Terhadap Pertimbangan Hakim Tentang Hak Haḍānah Kepada Ibu Murtad di Pengadilan Agama Bangkalan (Studi Putusan No. 1284/Pdt.G/2014/PA.Bkl).4 Misalnya juga karya Andi Tenri Sucia, yang berjudul Kedudukan Hak Asuh Anak Pasca Terjadinya Perceraian Karena Salah Satu Orang Tuanya Murtad Menurut Hukum Positif dan Hukum Islam (Studi Perbandingan Pengadilan Negeri dan Pengadilan Agama di Makassar).5 Contoh

4 M. Alfian Azizi, "Analisis Hukum Islam Terhadap Pertimbangan Hakim Tentang Hak Hadanah Kepada Ibu Murtad di Pengadilan Agama Bangkalan (Studi Putusan No. 1284/Pdt.G/2014/PA.Bkl)" (Skripsi-UIN Sunan Ampel, Surabaya, 2018).

5 Andi Tenri Sucia, "Kedudukan Hak Asuh Anak Pasca Terjadinya Perceraian Karena Salah Satu Orang Tuanya Murtad Menurut Hukum Positif dan Hukum Islam (Studi Perbandingan Pengadilan Negeri dan Pengadilan Agama di Makassar)", (Skripsi-UIN Alauddin, Makassar, 2017). 
lainnya karya Ida Nur Rohmatin yang berjudul "Hak Haḍanah Terhadap Istri yang Murtad Ditinjau dari Fikih dan Hukum Positif (Studi Analisis Putusan Pengadilan Agama Purwokerto Nomor: 1516/Pdt.G/2013/PA.Pwt),6 atau karya Abu Wafa Suhada' yang berjudul Haḍ̄nah dalam Perceraian Akibat Istri Murtad (Studi Analisis Putusan No. 1/Pdt.G/2013/PA.Blg), 7 serta karya Mochamad Firdos yang berjudul Tinjauan Mașlahah Mursalah Terhadap Haḍānah Ibu Murtad (Analisis Putusan Pengadilan Agama Maumere Nomor 1/Pdt.G/2013/PA.Mur).8

Sebagaimana hasil konfirmasi data awal, para hakim di lingkungan Peradilan Agama, mayoritas masih memegang teguh dasar hukum yang ada dalam undang-undang khususnya dalam lingkup hak asuh anak, tetapi ada pula beberapa hakim yang mendasarkan keputusannya pada kitab klasik atau sumber hukum tidak tertulis lainnya seperti Hadis dan alQuran. Pada hipotesisnya, hakim di lingkungan Peradilan Agama Islam berpandangan, bahwa menyelamatkan aqidah anak merupakan hal yang penting sehingga dalam memutuskan hak asuh anak yang salah-satu orang tuanya murtad merupakan sebuah kewajiban agama di samping tugas konstitusional.

\section{Nalar Integrasi Fikih dan Psikologi Keluarga dalam Pandangan Hakim Agama Jawa Timur tentang Hak Asuh Anak Pasangan Murtad}

Peraturan tentang peradilan agama tertuang dalam Undang-Undang No. 3 Tahun 2006 Tentang Peradilan Agama

6 Ida Nur Rohmatin, "Hak Hadanah Terhadap Istri Yang Murtad Ditinjau dari Fikih dan Hukum Positif (Studi Analisis Putusan Pengadilan Agama Purwokerto Nomor: 1516/Pdt.G/2013/PA.Pwt)" (Skripsi-IAIN Purwokerto, 2015).

7 Abu Wafa Suhada', "Hadanah dalam Perceraian Akibat Istri Murtad (Studi Analisis Putusan No. 1/Pdt.G/2013/PA.Blg)” (Skripsi-UIN Maulana Malik Ibrahim, Malang, 2017).

8 Mochamad Firdos, "Tinjauan Maslahah Mursalah Terhadap Hadanah Ibu Murtad (Analisis Putusan Pengadilan Agama Maumere Nomor 1/Pdt.G/2013/PA.Mur)" (Skripsi-UIN Wali Songo, Yogyakarta, 2016). 
yang merevisi dan melengkapi Undang-Undang No.7 Tahun 1989 Tentang Peradilan Agama di Indonesia. Tidak hanya itu, lahir juga Undang-Undang No. 50 Tahun 2009 sebagai revisi kedua Undang-Undang No. 7 Tahun 1989 Tentang Peradilan Agama. Dalam undang-undang yang terakhir ini dijelaskan bahwa yang salah satu ruang lingkup kekuasaan Pengadilan Agama ialah menyidang perkara-perkara yang berkaitan dengan hak asuh anak di lingkungan pengasuhan orang tua atau keluarga beragama agama Islam.

Berkaitan dengan hak asuh anak pasangan murtad, setiap hakim mempunyai pandangan yang berbeda dalam menetapkan hak asuh anak; akan diberikan kepada bapak, ibu atau keluarga yang lain. Keputusan yang diberikan hakim sangat tergantung pada kondisi masing-masing keluarga demi menjamin keselamatan jasmani maupun rohani anak. Hal ini terbukti dengan dijumpainya berbagai pertimbangan dalam pendapat atau pandangan hakim Pengadilan Agama Jawa Timur dalam memutuskan perkara hak asuh anak pasangan murtad:9

1. Pertimbangan Hakim Terhadap Personal Anak

Semua putusan hakim tidak pernah lepas dari prinsip mashlahat, adil, dan manfaat. Setiap hakim mempertimbangkan segala sisi, baik itu normatif, sosial, psikologis, dan lainnya. Berbeda hakim, berbeda pula cara mempertimbangkan perkara yang ada, apalagi mengenai perkara yang kasuistik seperti perkara hak asuh anak orang tua murtad.

Berdasarkan pada pernyataan atau pandangan para hakim agama yang telah diwawancarai, mayoritas hakim mempertimbangkan aspek rohani sang anak. Aspek rohani dianggap sebagai aspek agama juga di dalamnya, sehingga agama mempunyai aspek terpenting dalam pertimbangan perkara pengasuhan anak, khususnya anak yang belum

9 Wawancara dengan Hakim di lingkungan Peradilan Agama di Jawa Timur tahun 2019 tentang pandangan hakim terkait hak asuh anak pasangan murtad. 
mumayyiz. Perkara haḍanah mèenjadi salah-satu perkara yang mempunyai dampak langsung terhadap perkembangan anak, terutama di lingkungan orang tua yang salah-satunya murtad atau keduanya berada dalam kondisi murtad. Maka aspek agama oleh para hakim di pengadilan agama harus menjadi pertimbangan yang utama.

Penulis menemukan beberapa argumenasi hakim dalam mempertimbangkan bahwa agama harus dikedepankan bila salah-satu orang tuanya murtad. Diantaranya, hakim melihat bahwa saat anak tersebut dilahirkan dalam lingkungan perkawinan yang berdasarkan agama Islam, maka pendidikan si anak juga harus dilanjutkan secara Islam sebagai konsekuensi dari perkawinan dan agama orang tuanya yang awalnya samasama Islam. Akidah anak juga mengikuti akidah orang tua saat anak dilahirkan, meski kemudian orang tua berpindah agama. Pertimbangan tersebut dimaksudkan untuk menghindarkan kemudaratan terhadap anak jika ternyata persidangan memutuskan memberikan hak asuh anak kepada ibu yang murtad atau ayah yang murtad. Drs. H. Asep Badruzaman, M.H., Hakim Pengadilan Agama Kabupaten Tuban, mengatakan dengan jelas mengani hal ini: "Entah pertimbangannya kayak gimana, untuk lingkup aqidah harus terselamatkan. Jadi undang-undang itu bisa kita simpangi demi hal tersebut." 10

Alasan lainnya dalam pertimbangan hakim adalah bahwa melindungi aqidah atau menyelamatkan agama sang anak merupakan kewajiban hakim, karena agama mempunyai nilai penting dan akan mempengaruhi perkembangan anak terutama dalam aspek rohani di masa yang akan datang.

2. Dasar Hukum Pertimbangan Putusan Hakim

Setiap hakim mempunyai dasar pertimbangan yang berbeda dalam memutuskan perkara hak haḍ̄nnah pasangan

10 Asep Badruzaman (hakim Pengadilan Agama Kabupaten Tuban), Wawancara, Tuban, 30 Juli 2019. 
murtad. Ada yang mempertahankan dasar pertimbangan normatif undang-undang, ada yang memakai pertimbangan normatif agama yang sepenuhnya mengacu pada ketentuan fikih. Ada pula yang mempertimbangkan keduanya dan berusaha mewujudkan keadilan terutama untuk anak di masa yang akan datang, sebagaimana disampaikan oleh Drs. Moch Rusdi, M.H, Hakim pengadilan agama kabupaten Nganjuk: "Pertimbangan hukum tidak harus memakai UU, karena sumber hukum itu tidak semata-mata tertulis saja, hukum yang tidak tertulis juga bisa menjadi pertimbangan atau dasar". "Biasanya kitab-kitab ulama' bisa jadi dibuat rujukan sebagai sumber hukumnya".11

Para hakim juga ada yang mendasarkan pertimbangan hukumnya dengan mempertahankan normativitas undangundang. Meskipun dalam hukum perkawinan di Indonesia tidak dituangkan secara tegas dalam pasal-pasalnya tentang istilah haḍ̄anah, tetapi disinggung perkara pengasuhan anak, berikut kewajiban-kewajiban untuk orang tua yang mengasuhnya. Baik dalam Undang-Undang Nomor 1 Tahun 1974 Tentang Perkawinan, Kompilasi Hukum Islam atau Undang-Undang Nomor 23 Tahun 2002 Tentang Perlindungan Anak, pada dasarnya menghendaki hal yang terbaik untuk sang anak dengan mempertimbangkan pengasuhannya di depan hakim.

Menurut hasil wawancara dengan para hakim, hal yang terbaik itu untuk anak adalah menjaga aspek rohani sebagaimana yang mereka maknai dari undang-undang sebagai aspek agama. Meski demikian, ada beberapa hakim yang tetap mempertahankan hak asuh anak tetap pada ibunya, meskipun ibu tersebut telah berpindah agama, karena itu merupakan ketentuan undang-undang yang mutlak dan harus dipatuhi oleh hakim.12

11 Moch Rusdi (hakim Pengadilan Agama Kabupaten Nganjuk), Wawancara, Nganjuk, 11 Agustus 2019.

12 Imam Khuzaini (hakim Pengadilan Agama Kabupaten Bondowoso), Wawancara, Bondowoso, 9 Agustus 2019. 
Selain itu, pada pasal 4 Undang-Undang 23 Tahun 2002 Tentang Perlindungan Anak dinyatakan, bahwa hak anak harus dijamin, terutama dalam perkembangannya. Selain itu, anak juga dijamin untuk melaksanakan keyakinan/ keagamaannya sesuai kemampuannya disamping pengawasan dan juga jaminan dari orang tua atau yang mengasuhnya. Para hakim juga menegaskan, bahwa prosedur sidang mulai dari pemeriksaan perkara hingga pemutusan atau eksekusi putusan harus berdasarkan perundang-undangan, karena undang-undang merupakan dasar dari tindakan hakim dalam memutuskan selain hukum lainnya.

Akan tetapi, khusus dalam lingkungan hakim Peradilan Agama, selain peraturan perundang-undangan yang berlaku umum sebagai sumber atau dasar hukum bagi setiap hakim dalam memutus perkara, juga terdapat Kompilasi Hukum Islam sebagai petunjuk hukum yang bersumber dari kitabkitab kuning para imam mazhab fikih. Terutama yang berkenaan dengan hadānah/ pengasuhan anak, baik tamyiz atau yang belum tamyiz, kitab-kitab fikih seringkali menjadi rujukan. Alasan mereka ialah, untuk mencapai suatu keadilan, khususnya untuk sang anak, meninggalkan mengutamakan dasar hukum selain peraturan perundangundangan yang berlaku secara umum masih diperbolehkan. Artinya, keadilan tidak hanya ada dalam peraturan perundang-undangan yang berlaku secara umum sebagai salah-satu sumber hukum, namun ada juga pada sumber hukum yang lain, semisal KHI yang berlaku khusus untuk umat Islam, atau sumber hukum tidak tertulis lainnya. Sehingga berdasarkan argumen fikih sebagai dasar hukum dalam perkara haḍānah, maka orang tua yang murtad otomatis gugur haknya, baik bapak maupun ibunya.

3. Pertimbangan Hakim Tentang Hak Asuh anak Orang Tua Murtad terhadap Psikologi Anak

Setiap orang mempunyai pemikiran yang berbeda, tak terkecuali hakim. Dalam setiap perkara hak asuh anak, hakim berhak berijtihad sesuai pemikiranya dengan 
mempertimbangkan sisi kemaslahatan, keadilan dan kemanfaatan. Tidak hanya itu, seorang hakim juga harus mempertimbangkan segi psikologi anak tersebut, seperti yang disampaikan oleh bapak Wahidin Ali bahwa hak asuh anak pasangan murtad ini akan berdampak pada psikologis anak yang nantinya akan mempengaruhi keyakinannya. Artinya seorang hakim juga mempertimbangkan kelanjutan kehidupan anak.13

Bapak Wahidin Ali, hakim pengadilan agama Pasuruan juga sependapat dengan hakim lainnya, bahwa hak asuh anak orang tua murtad sebelum mumayyiz tidak dapat dipukul rata kondisi psikologisnya. Setiap fase umur anak dapat merubah cara pandang hakim dalam memutuskan hak haḍ̄anah anak tersebut. Saat anak masih berusia 1 tahun, ia berhak ikut ibu karena kedudukan ibu sangat berpengaruh terhadap perkembangan jasmani anak, akan tetapi berbeda jika anak berusia 8-10 tahun. Anak yang masih kecil harus ibu meskipun ibu itu murtad, karna bayi masih membutuhkan asi ibu. Menurut Bapak Wahidin Ali, harus dipikirkan akibatnya bila diserahkan pada bapak, karena anak yang masih kecil butuh kasih sayang ibu, dari pada kasih sayang bapak. Tetapi jika anak berumur 10 tahun harus juga dilihat, sejak kecil ikut siapa. Kalau misalnya ikut ibu, kemudian yang murtad bapak, maka harus diserahkan hak asuhnya kepada ibu. Jika yang murtad itu ibu, sedangkan anak sudah berumur 10 tahun, maka hakim tidak hanya mempertimbangkan murtadnya ibu, tapi juga kehidupan keseharian anak saat bersama ibu: apakah si anak juga diasuh oleh nenek yang muslim, atau keluarga lainnya yang muslim. Hakim mempertimbangkan efek berikutnya.14

Semua hal tersebut dipertimbangkan hakim demi terlindungi dan terpeliharanya psikologi anak, aspek

13 Wahidin Ali (hakim Pengadilan Agama Kabupaten Pasuruan), Wawancara, Pasuruan, 10 Agustus 2019.

14 Ibid.; Asep Badruzaman (hakim Pengadilan Agama Kabupaten Tuban), Tuban, 30 Juli 2019. 
pertumbuhan atau perkembangan anak, terutama pertumbuhan mental anak sebagaimana dalam pasal 5 Undang-Undang Nomor 23 tahun 2002 Tentang Perlindungan Anak, Undang-Undang Nomor 1 Tahun 1974 Tentang Perkawinan, KHI dan juga sumber hukum lainnya yang tidak tertulis. Semua sepakat, bahwa selain perkembangan anak secara fisik yang harus dilindungai, aspek rohani harus juga dilindungi, baik yang berkenaan dengan sosial maupun aqidah yang menjadi tolok ukur penting dalam perkara pengasuhan anak di lingkungan peradilan agama.

Selain pertimbangan psikologi anak, hakim juga mempertimbangkan keterpenuhan kebutuhan material anak. Alasannya, bahwa kebutuhan anak tidak hanya dalam aspek psikologis saja yang harus dipenuhi, tetapi juga keterjaminan materi seperti terjaminnya pendidikan yang layak. Dari pernyataan hakim yang demikian, juga dijumpai penjelasan lain berkaitan dengan psikologi anak, yakni, gugurnya hak asuh anak terutama bagi ibu yang murtad, bukan berarti hubungan anak dan ibu juga ikut terputus seluruhnya, terutama bagi anak yang masih balita atau belum mumayyiz. Karena pada dasarnya, anak yang masih kecil atau belum mumayyiz masih memerlukan kasih sayang dari ibunya, sehingga dalam faktanya, meski eksekusi putusan hak asuh anak jatuh pada si bapak, si ibu masih boleh mengunjungi atau sesekali membawa anaknya dalam rangka hubungan kasih sayang orang tua dan anak. Demikian ditegaskan oleh para hakim, khususnya Bapak Husen hakim Pengadilan Agama Jember.15

Secara psikologis, posisi ibu memang lebih dekat hubungannya dengan si anak, namun bukan berarti si ibu dapat begitu saja melakukan hubungan dengan anak jika sang ibu telah berpindah agama atau murtad. Para hakim sepakat, bahwa harus ada pengawasan terhadap

15 Husen (hakim Pengadilan Agama Kabupaten Jember), Wawancara, Jember, 30 Juli 2019. 
pelaksanaan putusan agar tidak membahayakan aqidah sang anak. Namun karena kepentingan psikologis anak, maka ibu yang demikian tetap diperbolehkan berhubungan dengan anak. Terkait aqidah dan agama harus tetap dijaga meskipun pada aspek psikologis, keberadaan ibu tetap diutamakan.

Pada dasarnya, mayoritas hakim yang dimintai pandangan atau pendapatnya setuju bahwa aqidah dan agama si anak yang lahir dalam perkawinan Islam harus dijaga, selain sesuai dengan prinsip hukum agama yang dianut dalam asas personalitas di peradilan agama, juga demi keadilan (semua harus bermuara pada kebaikan anak) berdasar fakta, posita dan saksi di depan persidangan. Namun mayoritas hakim juga tidak bisa menafikan psikologis anak juga perlu diperhatikan.

\section{Hak Asuh Anak Pasangan Murtad Perspektif Fikih dan Psikologi Keluarga}

Berdasarkan hasil paparan data mengenai pandangan hakim pengadilan agama Jawa Timur tentang hak asuh anak pasangan murtad, ditemukan tiga sisi pandangan hakim, yakni (1) pandangan hakim berdasarkan kepentingan anak (2) pandangan hakim berdasarkan sisi normatif dan sisi fikih serta (3) pandangan hakim dari sisi psikologis.

Sebagaimana kita ketahui bersama, Islam mengenal pemeliharaan anak dengan sebutan haḍanah. Haḍanah atau pemeliharaan anak adalah kegiatan mengasuh, memelihara dan mendidik anak hingga dewasa atau mampu berdiri sendiri.16 Adapun pemeliharaan anak diambil dari pengertian istilah bahasa Arab "ḥaḍānah" atau dapat pula dibaca "ḥaḍ̄nah" yang berasal dari kata al-hidnu yang artinya: sisi, samping, arah, lambung, rusuk, anggota tubuh dari ketiak sampai ke pinggul17, dan meletakkan sesuatu pada tulang rusuk atau pangkuan, karena sewaktu menyusukan anaknya, ibu meletakkan pada pangkuan atau sebelah rusuknya, yang seakan-akan ia

16 Al-Sayyid Sābiq, Fiqh as-Sunnah, cet; II, (Beirūt: Dār al-Fikr, 1983), 160. 17Ahmad Warson Munawwir, Kamus al-Munawwir Arab Indonesia Terlengkap, edisi 2, (Surabaya: Pustaka Progressif, 1997), 274. 
melindungi dan memelihara anaknya.

Pandangan hakim dari sisi normatif tentang hak asuh anak pasangan murtad dapat dilihat dari berbagai perundangundangan di Indonesia, seperti Undang-Undang No. 1 Tahun 1974 Tentang Perkawinan, Kompilasi Hukum Islam (KHI), hingga undang-undang perlindungan anak. Akan tetapi, dalam Undang-Undang No. 1 Tahun 1974 Tentang Perkawinan belum dikenal istilah haḍanah, hanya ada istilah pengasuhan anak. Selain itu, tidak ada satupun aturan atau pasal yang menyatakan bahwa hak asuh seorang ibu/ayah gugur karena pindah agama.

Dalam ketentuan pasal 1 ayat (11) Undang-Undang No. 1 Tahun 1974 Tentang Perkawinan, dijelaskan pengertian kekuasaan orang tua yang dalam mengasuh dan menumbuhkembangkan anak, yaitu harus sesuai dengan agama yang dianutnya. Sementara Pasal 42 ayat (2) UU tersebut menyatakan, bahwa agama anak, sebelum ia dapat menentukan pilihannya, mengikuti agama orang tuanya, tanpa ada penjelasan bagaimana jika agama kedua orang tuanya berbeda. sedangkan Pasal 31 ayat (4) mengatur kuasa asuh yang dilaksanakan oleh selain orang tua kandung, jika ternyata orang tua kandung tidak ada, atau tidak diketahui keberadaannya, atau karena suatu sebab tidak dapat melaksanakan kewajiban dan tanggung jawabnya sehingga dialihkan ke keluarga atau orang perseorangan atau lembaga pemerintah/masyarakat yang disyaratkan harus seagama dengan si anak.18

Namun mengenai kewajiban orang tua terhadap anaknya setelah terjadi perceraian, sudah diatur dalam pasal 41 tentang akibat putusnya perkawinan karena perceraian berikut ini: 19

a. Baik ibu atau bapak tetap berkewajiban memelihara dan mendidik anak-anaknya, semata-mata berdasarkan

18Undang-Undang Nomor 23 Tahun 2002, Tentang Perlindungan Anak. 19 Undang-Undang Nomor 1 Tahun 1974 Tentang Perkawinan. 
kepentingan anak, bilamana ada perselisihan mengenai penguasaan anak, pengadilan memberi keputusannya.

b. Bapak yang bertanggung jawab atas semua biaya pemeliharaan dan pendidikan yang diperlukan anak itu, bilamana bapak dalam kenyataan tidak dapat memberi kewajiban tersebut, pengadilan dapat menentukan bahwa ibu ikut memikul biaya tersebut.

c. Pengadilan dapat mewajibkan kepada bekas suami untuk memberikan biaya penghidupan dan atau menentukan sesuatu kewajiban bagi bekas istri.

Pasal 41 di atas, digunakan oleh Bapak Ghufran Sulaiman, hakim Pengadilan Tinggi Agama Jawa Timur sebagai pertimbangan dalam memutus perkara hak asuh anak orang tua murtad. Ia menyatakan, bahwa dalam hal pengasuhan anak harus semata-mata berdasarkan kepentingan anak tersebut, bukan lagi melihat kemurtadan salah satu orang tuanya. Selain itu, dalam pasal 45 bab X juga ditegaskan, bahwa kedua orang tua wajib memelihara dan mendidik anak-anak mereka sebaikbaiknya. Kewajiban yang dimaksud yakni berlaku sampai anak itu kawin atau dapat berdiri sendiri, kewajiban juga berlaku terus meskipun perkawinan antara kedua orang tua putus. 20

Istilah hadānah sebagai istilah yang umum dalam fikih baru muncul dalam Kompilasi Hukum Islam (KHI) dengan definisi: kegiatan mengasuh, memelihara dan mendidik anak hingga dewasa atau mampu berdiri sendiri sebagaimana dalam bab XIV tentang pemeliharaan anak, yang terdiri dari beberapa pasal didalamnya yakni pasal 98, 105 dan 156.21 Pandangan Bapak Wahidin Ali mengacu pada KHI pasal 105 yang memberikan hak hadānah anak sebelum mumayyiz atau belum berumur 12 tahun kepada ibunya. Sedangkan pemeliharaan anak yang sudah mumayyiz diserahkan kepada anak untuk memilih diantara ayah atau ibunya dengan biaya pemeliharaan

\footnotetext{
20 Ghufran Sulaiman (hakim Pengadilan Tinggi Agama, Surabya), Wawancara, Surabaya, 05 Agustus 2019.

21 Intruksi Presiden (Inpres) No. 1 Tahun 1991 Tentang Penyebarluasan Kompilasi Hukum Islam di Indonesia.
} 
ditanggung oleh ayahnya. Kemudian ada pengecualian hak atas haḍ̄nah bila ibu telah meninggal dunia, dalam KHI dijelaskan bahwa yang berhak atas hak hadānah anak tersebut adalah sebagaimana yang tertera dalam pasal $156 \mathrm{KHI}$.

Beberapa hakim mengartikan pasal 156 huruf (c) yang berbunyi: apabila pemegang hadānah ternyata tidak dapat menjamin keselamatan jasmani dan rohani anak, meskipun biaya nafkah dan haḍānah telah dicukupi, maka atas permintaan kerabat yang bersangkutan, Pengadilan Agama dapat memindahkan hak haḍānah kepada kerabat lain yang mempunyai hak haḍ̄nah pula. Selain itu, Beberapa hakim berpandangan, bahwa hak asuh ibu sebagai asal dari hak asuh anak akan menjadi gugur apabila ibu tersebut murtad. Hal ini sesuai dengan Yurisprudensi Mahkamah Agung RI No: 210/K/AG/1996, yang mengandung abstraksi hokum, bahwa agama merupakan syarat untuk menentukan gugur tidaknya hak seorang ibu atas pemeliharaan dan pengasuhan (hadānah) terhadap anaknya yang belum mumayyiz atau belum menginjak umur 12 tahun.

Pandangan hakim lainnya yang berkesesuaian dengan ketentuan fikih mengenai hak haḍ̄nah, yaitu selama tidak ada hal-hal yang melarang dan anak belum memiliki kemampuan untuk memilih, ibulah yang paling berhak untuk mengasuh anaknya, karena ibu mempunyai kasih sayang yang lebih. Di samping itu wanita pada umumnya lebih sering di rumah sedang laki-laki banyak mempunyai pekerjaan di luar rumah.22 Akan tetapi apabila ibunya menikah, maka praktis hak haḍānah tersebut beralih kepada ayahnya. Alasan yang dikemukakan adalah, bahwa apabila ibu menikah, besar kemungkinan perhatiannya akan beralih kepada suaminya yang baru dan mengalahkan atau mengorbankan anak kandungnya.23 Pernyataan di atas juga dikemukakan oleh Bapak Husen bahwa hak hậānah ketika ibu ketika ia menikah, akan beralih pada

22 Al-Sayyid Sābiq, Fiqh as-Sunnah., 205.

23 Ahmad Rofiq, Hukum Islam di Indonesia, (Jakarta: PT. Raja Grafindo Persada, 2000), 250. 
ayah. Pernyataannya ini mengacu pada ketentuan fikih yang telah mengatur syarat-syarat dalam hak haḍānah.24 Para hakim beranggapan, bahwa jika salah satu dari syarat-syarat tersebut tidak terpenuhi, maka hak seseorang dalam hal haḍānah sebagaimana telah dijelaskan di atas akan gugur.

Imam Asy-syatibi mengemukakan tiga syarat yang harus dipenuhi, sehingga suatu perbuatan itu dilarang, yaitu:

a. Perbuatan yang boleh dilakukan itu membawa kepada kemafsadatan.

b. Kemafsadatan lebih kuat dari kemaslahatan pekerjaan, dan

c. Dalam melakukan Perbuatan yang dibolehkan unsur kemafsadatannya lebih banyak.

Kemurtadan Jelas sebuah kemafsadatan. Kemudian para ulama' mengutamakan menolak segala kerusakan, daripada menolak segala kemaslahatan, Oleh karena itu apabila terdapat pertentangan antara mafsadah dan maslahah, maka yang didahulukan adalah menolak kerusakan, sebagaimana kaidah menolak kerusakan lebih utama dari menarik kemaslahatan).

Setelah melihat sebab-sebab dan pemaparan di atas, hak asuh anak haḍanah adalah mutlak hak seorang ibu selama ibu memenuhi syarat untuk menjadi seorang hādin (pengasuh). Namun hak Ibu sebagai hādin dapat dicabut oleh yang berwenang, yakni majlis hakim, jika ada persengketaan tentang hak asuk anak karena sebab-sebab tertentu, misalnya jika ibu keluar dari Agama Islam atau murtad. Memberikan hak asuh anak kepada seseorang yang berbeda agama, meskipun itu adalah seorang ibu, mafsadatnya lebih banyak dari pada maslahatnya. Mafsadatnya tentu harus dihilangkan berdasarkan kaidah Fiqh الضراريزال (segala mudharat (bahaya, kerugian) harus dihilangkan)."

Kemurtadan itu membawa kemafsadatan dilihat dari

24 Al-Sayyid Sābiq, Fiqh as-Sunnah, VIII, 209-210,; Abdurrahman al-Jazīrī, al Fiqh 'alā Madhāhib al-Arba'ah, (Beirut: Dar al-Hadis, 1994), 566-567.; Wahbah al-Zuhaili, al-Fiqh al-Islāmī wa Adillatuhu, jus VII, cet. ke-3. (Beirūt: Dār al-Fikr, 1989), 727. 
segi kualitas kemafsadatannya, yakni kemungkinan akan membawa kemafsadatan, meskipun hanya sebuah dugaan namun itu adalah dugaan keras, maka harus dihindari. Dari segi kemafsadatan yang ditimbulkan perbuatan itu pada dasarnya boleh atau bahkan dianjurkan. Yakni ibu asalnya boleh bahkan sangat dianjurkan untuk mengasuh anak karena lebih berkasih sayang, namun murtad adalah jalan yang menghalangi untuk memperoleh hak asuh anak.

Namun jika anak tersebut telah mumayyiz (dewasa) maka hak hadānah diberikan sepenuhnya kepada anak untuk memilih diantara kedua orang tuanya dengan berdasarkan hadis Nabi yang diriwayatkan oleh Abu Hurairah r.a yang menerangkan, bahwa kategori anak yang dimaksud adalah seorang anak yang sudah mampu membantu ibunya mengambil air di sumur, diperkirakan berumur di atas tujuh tahun atau mumayyiz. Berdasarkan hadis Abu Hurairah r.a tersebut, anak yang sudah mumayyiz atau sudah dianggap mampu menentukan pilihan sendiri, diberi hak untuk memilih sendiri.25

Para hakim juga ada yang berpandangan, bahwa ketika kedua orang tuanya murtad, maka yang berhak memelihara anak disesuaikan sebagaimana urutan urutan menurut ulama' mazhab Syafi'iyah, yakni ibu kandung, nenek dari ibu, nenek dari bapak, saudari-saudari si anak, bibi, putri-putri saudara si anak, putri-putri saudari si anak, bibi dari bapak, semua mahram waris sesuai tertib waris.26 Karna dengan diberikannya hak asuh pada saudara seagama yang sesuai urutan di atas, maka masa depan agama anak akan terjaga.

\section{Integrasi Fikih dan Psikologi Keluarga Tentang Hak Asuh Anak Pasangan Murtad}

Dalam fikih hak asuh anak disebut dengan hadānah. Ketika terjadi perceraian, ibulah yang paling berhak untuk

25 Ibn Mājah, Sunan Ibnu Mãjah, hadis nomor 2351, I, (Beirūt: Dār al-Fikr, 1995), 739.

26 Wahbah al-Zuhaili, al-Fiqh al-Islāmī wa Adillatuhu, jus VII, cet. ke-3. (Beirūt: Dār al-Fikr, 1989), 718. 
mengasuh anaknya selama tidak ada hal-hal yang melarang dan anak belum memiliki kemampuan untuk memilih, karena ibu dipandang mempunyai kasih sayang yang lebih. Di samping itu wanita pada umumnya lebih sering di rumah sedang laki-laki banyak mempunyai pekerjaan di luar rumah.27 Dilihat dari sisi psikologi, ibu lebih sering berdekatan dengan anak sehingga anak merasa nyaman dengan sosok ibu. Akan tetapi, apabila ibu menikah, maka hak haḍ̄anah tersebut beralih kepada ayah. alasan yang dapat dikemukakan adalah bahwa apabila ibu anak tersebut menikah, maka besar kemungkinan perhatiannya akan beralih kepada suaminya yang baru dan mengalahkan atau mengorbankan anak kandungnya.28

Namun jika anak tersebut telah mumayyiz (dewasa) maka diberikan sepenuhnya hak kepada anak untuk memilih di antara kedua orang tuanya dengan berdasarkan hadis Nabi yang diriwayatkan oleh Abu Hurairah r.a yang menerangkan, bahwa kategori anak yang dimaksud adalah seorang anak yang sudah mampu membantu ibunya mengambil air di sumur, diperkirakan berumur di atas tujuh tahun atau mumayyiz. Dengan demikian hadis di atas menunjukkan bahwa anak yang sudah mumayyiz atau sudah dianggap mampu menentukan pilihan sendiri diberi hak untuk memilih sendiri.29

Hak asuh anak pasangan murtad juga tidak dilepaskan dari pengasuhan oleh keluarga. Akan diberikan pada ibu atau ayahnya, atau yang lain dalam keluarganya. Karena dalam keluarga terdapat keselarasan hubungan yang terjadi secara intensif serta terpenuhinya fungsi kebutuhan baik secara fisik maupun psikis. Orang tua adalah contoh bagi atau model bagi anak. Orang tua mempunyai pengaruh yang sangat kuat bagi anak. Ini dapat dilihat dari bagaimana orang tua mewariskan cara berfikir kepada anak-anaknya. Orang tua juga merupakan mentor pertama bagi anak yang menjalin hubungan dan

27 As-Sayyid Sābiq, Fiqh as-Sunnah, (Beirūt: Dār al-Fikr, 1968), 205.

28 Ahmad Rofiq, Hukum Islam di Indonesia, (Jakarta: PT. Raja Grafindo Persada, 2000), 250.

29 Ibn Mājah, Sunan Ibnu Mājah, hadis nomor 2351, I, (Beirūt: Dār al-Fikr, 1995), 739. 
memberikan kasih sayang secara mendalam, baik positif atau negatif pasti berpengaruh pada perkembangan kepribadian anak. Pernyataan di atas sesuai firman Allah tentang kewajiban pemeliharaan anak (haḍ̄nah) dalam surat At-Tahrīm: 66 ayat (6).

Dalam ayat tersebut dijelaskan, bahwa Allah SWT memerintahkan kepada orang-orang yang beriman untuk memelihara dirinya dan keluarganya dari api neraka, dengan berusaha agar seluruh anggota keluarganya melaksanakan semua perintah-perintah Allah dan meninggalkan semua larangan-larangan Allah.30 Pemeliharaan anak merupakan tanggung jawab kedua orang tuanya (suami-isteri). Sedangkan masalah biaya pemeliharaan anak serta nafkah keluarga merupakan tanggung jawab ayahnya (suami). Hak memelihara terletak di tangan isteri. Dasar hukum menafkahi anak dan isteri tertera dalam firman Allah pada surat Al-Baqarah: 2 ayat (233).

Setiap keluarga juga mempunyai tujuan untuk mewujudkan kesejahteraan lahir (fisik, ekonomi) dan batin (sosial, psikologi, spiritual, dan mental). Sebagai unit terkecil dalam masyarakat, keluarga memiliki kewajiban untuk memenuhi kebutuhan-kebutuhan anggota keluarganya yang meliputi kebutuhan fisik (makan dan minum), psikologi (disayangi/ diperhatikan), spiritual/ agama, dan sebagainya. Nilai fikih dan psikologi keluarga tentang hak haḍānah orang tua murtad sangat berhubungan. Hal ini terlihat jelas, dalam kacamata fikih yang memberikan syarat-syarat kebolehan dalam menyelenggarakan haḍānah yakni antara lain:

a. Baligh. Pelaku haḍanah harus balig, sebab anak kecil sekalipun sudah tamyiz, tetap masih membutuhkan orang lain untuk mengurusi urusannya dan mengasuhnya. Karena itu, ia tidak boleh mengurusi orang lain.

b. Berakal sehat. Orang gila dan orang kurang waras akalnya tidak boleh melakukan haḍ̄nah karena mereka tidak dapat

30 Tihami dan Sohari Sahrani, Fikih Munakahat: Kajian Fikih Nikah Lengkap, (Jakarta: Rajawali Pers, 2009), 216-217. 
mengurusi urusannya sendiri dan masih membutuhkan orang lain untuk mengurusnya.

c. Mampu melakukan tugas pengasuhan anak. Orang yang lemah badannya, sakit, cacat jasmaninya, atau sudah tua dan tidak mampu melakukan tugas untuk mengasuh anak, maka tidak berhak melakukan haḍanah.

d. Memiliki sifat amanah dalam mendidik anak. Orang yang curang atau tidak memiliki sifat amanah tidak aman bagi anak yang di asuhnya dan tidak dapat dipercaya untuk melakukan kewajibannya dengan baik. Bahkan mungkin anak itu akan meniru atau berkelakuan seperti orang yang mengasuhnya.

e. Merdeka (bukan budak). Budak tidak berkuasa atas dirinya sendiri (berada di bawah kekuasaan tuannya) sehingga tidak mampu mengurusi urusan orang lain.

f. Jika pelaku hadānah ibunya, maka disyaratkan dia belum menikah dengan laki-laki lain, apabila ia menikah maka gugur hak asuhnya.

g. Islam. Fuqahā' berbeda pendapat mengenai syarat ini. Fuqaha' mazhab Syafi'i dan Hambali mensyaratkan Islam bagi pelaku hadānah sehingga seorang istri yang kafir tidak berhak melakukan haḍānah terhadap orang Islam, karena tidak ada hak walāyah terhadapnya dan dikhawatirkan akan menyesatkan anak dari agamanya. Sedang Fuqahā' mazhab Hanafi dan Maliki tidak menyaratkan Islam bagi pelaku haḍ̄anah karena Rasulullah telah memberikan hak pilih kepada seorang anak untuk diasuh oleh ayahnya yang Islam atau ibunya yang kafir. Di samping itu dasar haḍanah adalah kasih sayang dan hal itu tidak akan terpengaruh dengan adanya perbedaan agama. 31

Dalam syarat ini terdapat ketentuan bahwa harus beragama Islam. Artinya, jika salah satu orang tua murtad maka anak akan mengikut pada orang tua yang masih Islam. Hal ini

31 al-Sayyid Sābiq, Fiqh as-Sunnah, VIII, 209-210; Abdurrahman al-Jazīrī, al Fiqh 'alā Mazāhib al-Arba'ah, 566-567; Wahbah al-Zuhailī, al- Fiqh al-Islāmī., 727. 
sangat berkaitan dengan psikologi keluarga karena keluarga harus memberikan contoh atau model pendidikan Islam bagi anak. orangtua mempunyai pengaruh yang sangat kuat terkait pendidikan keagamaan anak. Keluarga yang memiliki anak pada usia 0-2 tahun wajib memperhatikan perkembangan anak pada usia tersebut, karena menurut Piaget, usia tersebut merupakan usia sensori motor dan pra operasional awal. Berikut ini adalah alasan mengapa hak asuh anak harus diserahkan pada orang tua yang beragama Islam:32

1. Intelengensi anak lebih didasarkan pada tindakan inderawi anak terhadap lingkungannya seperti melihat, meraba, menjamah, mendengar, membau dan lain-lain. Hal ini akan berdampak bahaya pada anak ketika anak ada dalam pengasuhan orang tua murtad, karena ia secara langsung mengetahui apa yang dilihat dari keseharian orang tua, seperti contohnya ketika seorang ibu atau bapak yang murtad melakukan ibadah maka secara tidak langsung juga akan melihat ibadah dari orang tuanya.

2. Perkembangan kognitif seorang anak bertumpu pada tahap sensorimotor karena dalam tahap ini anak masih dalam keadaan meniru dan bersifat aktual. Orangtua dalam proses pengasuhan di keluarga harus memperhatikan sifat tersebut. Harus hati-hati bersikap sehingga anak dapat meniru hal positif yang berguna bagi tahap perkembangan selanjutnya. Dalam tahapan ini seoorang anak telah menirukan berbagai macam tingkah laku orang tuanya maka sangat disayangkan ketika nantinya pengasuhan anak akan diberikan pada orang tua yang murtad, karena bisa jadi dengan bertumpu pada tahap sensorimotor, anak akan menirukan apa yang dilakukan orang tuanya, terlebih masalah ibadah. Jika seorang anak dididik menjadi muslim maka pada perkembangan kognitif ini anak akan bisa menirukan gaya sholat, mengaji dan lain sebagainya, akan sangat berbahaya ketika ia sampai diasuh oleh orang tua yang murtad karna

32 Suparno Paul, Teori Perkembangan Kognitif Jean Piaget, (Yogyakarta: Kanisius 2001), 102. 
tidak menuntut kemungkinan akan menirukan keseharian orang tuanya seperti pergi ke tempat peribadatan dan lain sebagainya.

Orang tua harus selalu memberikan latihan-latihan dalam menggunakan indera anak supaya perkembangan pemikiran sensori motornya berkembang. Tindakan tersebut akan membantu anak mengembangkan self-regulasi untuk mencapai suatu ekulibrasi dalam proses pemikirannya. Pada tahap ini orang tua sudah mulai melatih anaknya untuk mengerjakan segala sesuatu yang baik. Baik dari segi agama maupun sosial. Ketika anak berada di bawah pengasuhan orang tua yang muslim, ia akan senantiasa dididik menjadi anak muslim yang taat pada agama, taat pada perintah Allah dan menjalankan segala ketentuan-ketentuan Islam, misalnya anak dilatih untuk menjalankan sholat dan puasa.

Keluarga, terutama orang tua dalam menjalankan perannya dan stimulasinya harus memperhatikan tiga hal, yakni intelegensi anak, perkembangan kognitif, dan optimalisasi indera anak. Pendidikan anak menurut Robert M. Berns dapat dioptimalkan melalui keluarga, karena keluarga dapat memberikan ruang lingkup psikologis yang mempunyai poin-poin penting yang harus dibentuk agar melahirkan generasi yang baik. Bangunan keluarga harus didasari oleh pondasi yang kuat, seperti Cinta, dorongan fitrah dan etos ibadah yang oleh para psikolog disebut sebagai pondasi utamanya. Dalam hal ini etos ibadah menjadi penting dipakai untuk hak asuh anak orang tua murtad, artinya dalam hal etos ibadah ini menunjukkan adanya kesungguhan dalam menunaikan Ibadah yang akan menjadi pondasi kehidupan keluarga bagi yang patuh kepada agama, karena mereka menyadari bahwa semua aktifitas dalam kehidupan keluarga bahkan sampai kegiatan seksual antara suami dan istri merupakan nilai ibadah.

Al-Qur'an memandang bahwa anak adalah amanah bagi orang tuanya, dalam artian bahwa, anak bukanlah milik orang tuanya, melainkan hanya titipan Allah untuk orang tua jaga. Ketika orang tuanya murtad, maka anak harus dilindungi 
aqidahnya. Sudah menjadi kewajiban pengasuh yang muslim untuk mendidik anak sesuai dengan yang telah Allah perintahkan. Sementara itu, terdapat dua faktor yang dapat mempengaruhi perkembangan seorang anak, yaitu faktor internal dan eksternal. Faktor internal dapat berupa kondisi, fisik, psikis, dan moralitas anggota keluarga yang dalam hal ini, orang tua merupakan elemen utama. Sementara faktor eksternal misalnya perkembangan sosial budaya. Setiap keluarga berbda-beda sebab perbedaan kondisi sosial budayanya. Ada anggota keluarga yang merasa nyaman dan bahagia dan ada juga keluarga yang mengalami broken home. Karena keretakan atau ketidakharmonisan inilah, anggota keluarga merasa tidak bahagia. 33

Mengenai perkembangan anak, Livina Dewi, psikolog Universitas Indonesia mengatakan, dampak psikologis yang dialami anak, dipengaruhi oleh dua hal: Kepribadian dan gender si anak, serta bagaimana penghayatan seorang ibu/ayah terhadap peran yang dijalaninya. Pada anak-anak yang memiliki sikap tegar atau cuek mungkin dampaknya tidak terlalu terlihat, tetapi untuk anak yang sensitif pasti akan terjadi perubahan perilaku, misalnya menjadi pemurung atau suka menangis diam-diam. Hal ini terjadi pada anak yang orang tuanya bercerai. Selain itu, jika anak yang kedua orang tuanya bercerai masih balita, maka perkembangan mental/psikologis dan fisiknya, juga akan sangat terpengaruh.34

\section{Penutup}

Pandangan hakim Pengadilan Agama Jawa Timur tentang hak asuh anak pasangan murtad terbagi menjadi tiga sisi, yakni sisi normatif yang yang mengacu pada Undang-Undang No.1 Tahun 1974 Tentang Perkawiinan, KHI, Undang-Undang No.7 tahun 1989 Jo. Undang-Undang No. 30 tahun 2006 tentang pemeliharaan anak, Undang-Undang No. 23 Tahun 2002

33 Syamsu, Yusuf, Perkembangan Anak dan Remaja, (Bandung: PT. Rineka Cipta, 2011), 39.

34 Qaimi A, Single Parent: Peran Ganda Ibu dalam Mendidik Anak, terj. MJ. Bafaqih, Cet-I. (Bogor: Cahaya 2003), 157. 
Tentang Perlindungan Anak, Yurisprudensi MA RI No. 210/K/AG/1996. Kemudian sisi fikih mengacu pada syaratsyarat hadānah sesuai fikih dan sesuai urutan pemilik hak asuh berdasarkan pendapat Imam Syafi'i. Sedangkan dari sisi psikologis, yakni hakim dapat memahami setiap permasalahan yang menyangkut anak dari sisi psikologis. Baik sikap atau langkah yang diambil oleh hakim, maupun cara eksekusinya haruslah tidak mengganggu mental dan psikologis anak. Kekhawatiran akan berpindahnya aqidah anak ketika hak asuh diberikan pada orang tua murtad, hak asuh anak orang tua murtad yang hilang, bukan berarti menghilangkan hak untuk menyalurkan kasih sayang pada anaknya.

Integrasi fiqih dan psikologi dalam pandangan hakim Pengadilan Agama Jawa Timur tentang hak asuh anak pasangan murtad, yakni dalam nilai-nilai fikih terdapat syarat-syarat yang berhak mengasuh anak harus beragama Islam, karena tidak ada hak walāyah terhadapnya dan dikhawatirkan akan menyesatkan anak dari agamanya. Hal ini sejalan dengan nilainilai psikologi, bahwa keluarga harus memberikan contoh atau model pendidikan Islam bagi anak, orangtua mempunyai pengaruh yang sangat kuat terkait pendidikan keagamaan, pembentukan mental kerohanian anak, hal ini dapat dilihat dari bagaimana orangtua mewariskan cara berpikir kepada anakanaknya, kemudian bagaimana cara orang tua mengembangkan kepribadian anak sehingga nantinya kepercayaan anak tetap pada Islam.

\section{Daftar Pustaka}

Azizi, M. Alfian. "Analisis Hukum Islam Terhadap Pertimbangan Hakim Tentang Hak Hadanah Kepada Ibu Murtad di Pengadilan Agama Bangkalan (Studi Putusan No. 1284/Pdt.G/2014/PA.Bkl)" (Skripsi-UIN Sunan Ampel, Surabaya, 2018).

Firdos, Mochamad. "Tinjauan Maslahah Mursalah Terhadap Hadanah Ibu Murtad (Analisis Putusan Pengadilan Agama Maumere Nomor 1/Pdt.G/2013/PA.Mur)" (Skripsi-UIN Wali Songo, Yogyakarta, 2016). 
Intruksi Presiden (Inpres) No. 1 Tahun 1991. Kompilasi Hukum Islam di Indonesia

Jazīrī (al), Abdurraḥman. al Fiqh 'alā Madhāhib al-Arba'ah, , VII Munawwir, Ahmad Warson. Kamus al-Munawwir Arab Indonesia Terlengkap, edisi 2. Surabaya: Pustaka Progressif, 1997.

Mājah, Ibn. Sunan Ibnu Mājah, hadis nomor 2351, I. Beirūt: Dār al-Fikr, 1995.

Partanto, Pius A. dan M. Dahlam Al- Barry. Kamus Istilah Poluler Lengkap. Surabaya: Arkola, 1994.

Paul, Suparno. Teori Perkembangan Kognitif Jean Piaget. Yogyakarta: Kanisius 2001.

Qaimi A, Single Parent: Peran Ganda Ibu dalam Mendidik Anak, terj. MJ. Bafaqih, Cet-I. Bogor: Cahaya 2003

Rianto, Adi. Metodologi Penelitian Sosial dan Hukum. Jakarta: Granit, 2004.

Rofiq, Ahmad. Hukum Islam di Indonesia. Jakarta: PT. Raja Grafindo Persada, 2000.

Rohmatin, Ida Nur. "Hak Hadanah Terhadap Istri Yang Murtad Ditinjau dari Fikih dan Hukum Positif (Studi Analisis Putusan Pengadilan Agama Purwokerto Nomor: 1516/Pdt.G/2013/PA.Pwt)" (Skripsi-IAIN Purwokerto, 2015).

Sābiq, As- Sayyid Fiqh as- Sunnah, cet; II. Beirūt: Dār al-Fikr. 1983.

Singarimbun, Irawati. Teknik Wawancara: Metode Penelitian Survey. Jakarta: LP3ES, 1989.

Sucia, Andi Tenri. "Kedudukan Hak Asuh Anak Pasca Terjadinya Perceraian Karena Salah Satu Orang Tuanya Murtad Menurut Hukum Positif dan Hukum Islam (Studi Perbandingan Pengadilan Negeri dan Pengadilan Agama di Makassar)", (Skripsi-UIN Alauddin, Makassar, 2017).

Suhada', Abu Wafa. "Hadanah dalam Perceraian Akibat Istri Murtad (Studi Analisis Putusan No. 1/Pdt.G/2013/PA.Blg)" (Skripsi-UIN Maulana Malik Ibrahim, Malang, 2017). 
Syamsu, Yusuf. Perkembangan Anak dan Remaja. Bandung: PT. Rineka Cipta, 2011.

Tihami dan Sohari Sahrani. Fikih Munakahat: Kajian Fikih Nikah Lengkap. Jakarta: Rajawali Pers, 2009.

Zuhaili (al), Wahbah. al-Fiqh al-Islām wa Adillatuhu. juz VII, cet. ke-3. Beirūt: Dār al-Fikr, 1989.

Zuhaili (al), Wahbah. Fiqih Islam Wa Adilatuhu. terj. Abdul Hayyie Al-Kattani dkk. Jilid 9, Jakarta: Gema Insani, 2011

Undang-Undang No.1 Tahun 1974 Tentang Perkawinan

Undang-Undang Nomor 23 Tahun 2002, Tentang Perlindungan Anak.

Himpunan Undang-Undang Republik Indonesia Nomor 1 Tahun 1974 tentang Perkawinan \& Kompilasi Hukum Islam, Grahamedia Press, 2014 